\title{
SPORTUOJANČIŲ PAAUGLIŲ VERTYBINĖS ORIENTACIJOS KAIP SOCIALINĖS KOMPETENCIJOS VEIKSNYS
}

\author{
Dovilė Šertvytienė, Skaistė Laskienė \\ Lietuvos kūno kultūros akademija, Kaunas, Lietuva
}

\begin{abstract}
Dovilè Šertvytienė. Edukologijos magistrantè. Kauno Jono Jablonskio gimnazijos kūno kultūros ir etikos mokytoja. Mokslinių tyrimų kryp-
\end{abstract} tis - paaugliu psichologija.

\section{SANTRAUKA}

Paangliu vertybiniu orientaciju raiška - daugiaaspektè: paanglystès amžiaus tarpsniu jaunuoli veikia psichosocialinès ir kognityvinès raidos ypatumai, ¿̇vairüs vidiniai ir išoriniai veiksniai, todèl vertybiu tyrimai nepraranda savo aktualumo. Socialine kompetencija suprantama kaip individo gebèjimas veikti, nulemtas žiniu, mokèjimu, igūdžiu, požiūriu ir asmenybès savybiu bei vertybiu.

Tyrimo tikslas - nustatyti ir ìvertinti paaugliu vertybines orientacijas kaip socialinès kompetencijos veiksni veiklos ir lyties aspektu.

Buvo tiriami dvieju Kauno bendrojo lavinimo viduriniu mokyklu moksleiviai: 13-15 metu merginos ir vaikinai. Iš viso 400: 186 merginos ir 214 vaikinu. Respondentai parinkti netikimybiniu tiriamuju grupiu parinkimo büdu.

Anketinès apklausos metodu nustatyti respondentu vertybinès orientacijos ir socialinès kompetencijos ypatumai. Vertybinèms orientacijoms i vivertinti respondentams pateikta čeku psichologo B. Basso (Елисеев, 2000) anketa pagal 3 orientacijas: orientacija i save, orientacija i bendravima ir orientacija i veikla. Socialinés kompetencijos ypatumams vertinti naudota $R$. Lekavičienès (2001) parengta socialinès kompetencijos vertinimo metodika (adaptuota Ullrich ir de Muynck anketa), kuriq sudaro 45 teiginiai, atskleidžiantys socialinès kompetencijos raiškq.

Anketinès apklausos duomenys apdoroti matematines statistikos metodais. Skirtumui tarp grupiu rezultatu nustatyti buvo naudojamas chi kvadrato kriterijus.

Nustatyta: labiau pasikliauja savimi, geba bendrauti su pažistamais ir nepažistamais žmonèmis sportuojantys vaikinai ir sportuojančios merginos; kryptinga orientacija ì bendravima reikšmingai büdinga sportuojančioms merginoms ir nesportuojantiems vaikinams; kryptinga orientacija i veikla labai büdinga sportuojančioms merginoms ir vaikinams; kryptinga orientacija i save büdinga nesportuojantiems merginoms ir vaikinams.

Raktažodžiai: sportas, socialine kompetencija, vertybinès orientacijos.

\section{IVADAS}

$\mathrm{P}$ aauglystė yra bene vienas iš sudétingiausių asmenybès tapsmo laikotarpių. Tai būsimo gyvenimo kelio arba, kitaip tariant, tapatumo ieškojimo laikotarpis. Tapatumo krizę neretai lengviau iveikia tie paaugliai, kurie randa juos dominančią veiklą (viena iš ju gali būti sportinè), padedančią kryptingai siekti tikslo ir jausti pasitenkinima tos veiklos rezultatais. Sèkminga veikla patvirtina, kad žinios, mokejjimai, igūdžiai yra taikomi tinkamai, ir taip kuriamas kompetencijos pagrindas. Pasak J. Sookol (2001), kompetencija yra darbo uždaviniui ar vaidmeniui atlikti būtinų mokejjimo, igūdžių, žinių ir gebejjimų derinys. Kompetencijos sąvoka ir akademineje literatūroje, ir kasdienèse diskusijose paprastai vartojama plataus diapazono gebejimams, kurie kaip nors susiję su mūsų patirtimi, apibūdinti: meistriškumu, specializacija, inteligentiškumu ir problemų spren- 
dimu. J. Erpenbeck (1998) nuomone, kompetencija - tai gebejimas organizuotis. J. Sauer (1998) teigia, kad kompetencija apima vertybiu, elgsenos pokyčių, naujų žinių prièmimą, igyto patyrimo keitimą. Asmeninè (individuali) kompetencija - tai savęs įvertinimas (asmeninès žmogaus savybès), nusistatymas produktyviai dirbti, motyvavimas, mokslo ir tobulejimo siekimas tiek darbe, tiek už jo ribų. B. Martinkus ir kt. (2002) nurodo, kad kompetencija - tai žinių ir igūdžių derinimas bei gebejjimas juos pritaikyti konkrečiomis aplinkybèmis. Aptariant paauglystès psichosocialinès raidos ypatumus, be socialinès kompetencijos naudojama elgesio modelio sąvoka, kurią N. M. Grendstad (1996) apibūdina kaip nuolat ivvairiomis situacijomis ir aplinkybemis pasikartojančius elgesio būdus. Tai ypač svarbu kalbant apie paauglių elgesio ivairiomis situacijomis prognozavimą: tai, kokias vertybes yra prièmęs paauglys, arba kokių vertybiu siekia (vertybinès orientacijos), kurios nulems jo elgesî, ypač kritinėmis situacijomis, reikalaujančiomis pasirinkimo.

Anot R. Malinausko (2006), socialinė kompetencija - tai nusimanymas ir aukšta bendravimo kultūra. Socialiai kompetentingas žmogus visada laikosi visuomeneje priimtu elgesio normu ir profesinès etikos kodekso reikalavimu, išlieka orus net ir tada, kai priešinamasi jo sprendimams.

R. Lekavičienè $(2001,2004)$ teigia, kad laikydamiesi skirtingų socialinès kompetencijos sampratų mokslininkai ivardija skirtingus socialinès kompetencijos vertinimo rodiklius. Dažniausiai individo socialinès kompetencijos matais yra laikomi jo turimi socialiniai igūdžiai, gebejjimai siekti tikslu ir (arba) individo tarpasmeniniu santykiu kokybè. Be to, socialiné kompetencija gali būti tyrinejjama tiek teoriniu, tiek empiriniu lygmeniu. Pastarasis lygmuo taip pat nèra vienalytis: empiriniai tyrinejjimai gali būti atliekami specifiniu gebejjimų arba integruotų rodiklių lygmeniu.

Bandoma sudarinèti igūdžių sąrašus, pagal kuriuos būtų galima nustatyti kompetentingus žmones, kurti kompetencijos treniravimo programas. G. Gambrill (1995) (cit. iš Hinsch ir Pfingsten, 1998) išskiria tokius kompetentingo žmogaus socialinius igūdžius: gebejimą atsisakyti, reaguoti i kritiką, reikalauti pakeisti griaunamą elgesi, išreikšti prieštaravimus, neleisti nutraukinèti kalbant, atsiprašyti, pripažinti silpnybes, nutraukti nepageidaujamus kontaktus, reaguoti $\mathfrak{i}$ bandymus kontaktuoti, pradèti pokalbi, palaikyti pokalbi, baigti pokalbi, atvirai reikšti jausmus ir kt. Tačiau teoriniai samprotavimai ne visada patvirtinami empiriniais tyrinejjimais. Pavyzdžiui, socialiniu ryšių vengimas teoretikų buvo traktuojamas kaip rizikos veiksnys, kai tuo tarpu kiti autoriai irode, kad neretai socialinių ryšių vengimas ir gebejjimas juos apriboti gali būti vertinamas kaip reikalingas socialinis igūdis. Kitas trūkumas yra ir tas, kad kalbant vien apie igūdžius socialinè kompetencija dažniau įvardijama kaip gebejimas užmirštant tarpusavio santykių, elgesio aspektą. Todèl bandymai apibrezžti socialinę kompetenciją per socialinius igūdžius veda i nekonkretumą, nes toks pat elgesys ivairiomis situacijomis ir skirtingų individų gali būti vertinamas labai nevienodai.

Individo gebejjimas ugdyti teigiamus tarpasmeninius santykius yra laikomas labai svarbiu veiksniu norint, kad asmenybe vystytusi sveikai ir gerai adaptuotusi psichosocialine prasme. Pagal santykių palaikymo kokybę neretai vertinama ir individo socialinė kompetencija.

Tyrimo aktualumas grindžiamas tuo, kad analizuotų autorių aptariama socialinès kompetencijos samprata dažniausiai siejama su profesine veikla bei karjera ir naudojama socialinei kompetencijai tobulinti (mokymosi visa gyvenimą projektai), konstatuojant jos trūkumą, ir tik nedidelè dalis mokslininkų užsimena apie socialinès kompetencijos kaip socialinių igūdžių ugdymo galimybes mokykliniame amžiuje. Manytume, kad mokyklinio amžiaus vaikų socialinès kompetencijos kaip socialiniu igūdžių ugdymo galimybès galètų būti siejamos su sportine veikla, tačiau tenka pripažinti, kad šioje srityje nepakankamai dèmesio skiriama psichosocialinès ir kognityvinès raidos ypatumams, akcentuojama ne asmenybès ugdymo, o sportinio rezultato svarba, pasigendama sportinès patirties galimybiu panaudojimo socialinei kompetencijai ugdyti. Paauglystés laikotarpiu padidèję kognityviniai gebèjimai leidžia paaugliui suprasti ir iqvertinti, kokie reikšmingi yra pokyčiai, apgalvoti ateities ìvykius, skatina mąstyti apie karjerą, gyvenimą ir kitus svarbius pasirinkimus. Psichosocialinę paauglio raidą dauguma autoriu (Brettschneider, Heim, 1997) sieja su specifiniais uždaviniais, kuriuos jam kelia gyvenimas. Šiuos uždavinius veikia skirtingi biologiniai, asmenybès, socialiniai ir kultūriniai veiksniai. Jei jie įvykdomi sẻkmingai, tai padaro individą laimingą ir lemia tolesnę jo sèkmę, priešingu atveju, jie veda prie nusivylimo, visuomenès nesusitaikymo su sunkumais, susijusiais su ateities uždaviniais. Mokyklinio amžiaus vaikai kompetenciją suvokia kaip savo vertès pajautima. Manoma (Weiss, Amorose, 2005), kad paaugliams, kuriu suvokta kompeten- 
cija daugelyje sričių yra gera, būdingas pozityvus savęs vertinimas, jiems lengviau priimti gyvenimo iššūkius, mokymosi procesas jiems pasidaro įdomus, jie nebijo susidurti su sunkumais.

Pats intensyviausias vertybiniu orientaciju formavimasis vyksta paauglystejje, kada išryškèja asmens pozicija socialinių santykių aplinkoje. Būtent paauglystės tarpsniu jaunuoliui būdinga proto, emocijų ir valios emancipacija (Hart, Atkins, 1999). Savo ruožtu tèvų ir šeimos poveikis paaugliams ne sumažèja, o tik kokybiškai pakinta. Šeima, būdama dorovinių vertybiu, funkcionuojančiu visuomenèje, versme, tas gyvenimo prasmes ar vertybes surikiuoja pagal svarbą, vertina, paradigmina ir perduoda savo vaikams per bendravimą ir veiklą.

Mokslininkai (Fox, cit. iš Brettschneider, Heim, 1997; Oweis, Spinks, 2001; Danish et al., 2003; Klomsten et al., 2004; Moreno, Cervello, 2005) savo tyrimais pabrèžia, kad dalyvavimas sportineje veikloje yra vienas iš reikšmingiausiu veiksnių, prisidedančių prie paauglių tapatumo, veikiančių paauglio savivokos procesą, vertybines orientacijas, ir akcentuoja sportinès veiklos pozityvų poveiki bendradarbiavimui su bendraamžiais, fiziniu gebejjimų, charakterio, kūrybingumo, vertybių sistemos ugdymui. Tyrimo metu palyginsime sportuojančių ir nesportuojančių paauglių vertybines orientacijas.

Tyrimo objektas — sportuojančiu paauglių socialinès kompetencijos ypatumai: vertybinès orientacijos kaip socialinei kompetencijai turintis itakos veiksnys.

Tikslas - nustatyti ir įvertinti paauglių vertybines orientacijas kaip socialinei kompetencijai turinti itakos veiksnį veiklos ir lyties aspektu.

\section{TYRIMO METODIKA IR ORGANIZAVIMAS}

Metodai: 1) anketinè apklausa; 2) matematinès analizè. Anketinès apklausos metodu buvo nustatyti respondentu vertybinès orientacijos ir socialinès kompetencijos ypatumai. Vertybinèms orientacijoms ivvertinti respondentams buvo pateikta čeku psichologo В. Basso (Елисеев, 2000) anketa, išversta iš rusų kalbos, kurią sudare 29 klausimai: 2 bendrojo pobūdžio (nustatantys respondentų lyti ir fizini aktyvumą - sportuojantys paaugliai per savaitę sportuoja $2-3$ kartus, nesportuojantys 1 ir mažiau); 27 teiginiai - situacijos su trimis galimais atsakymų variantais, atitinkančiais tris vertybines orientacijas: orientacija $i$ save, orientacija i bendravimą ir orientacija i veiklą. Tiriamuju buvo prašoma atsakyti apibraukiant vieną teiginio varianta, kuris labiausiai atitinka jų nuomonę. Teiginiai buvo pateikiami atsitiktine tvarka, kurios kodavimas buvo žinomas tik tyrèjui. Socialinès kompetencijos ypatumams įvertinti naudojome R. Lekavičienès (2001) parengtą socialinès kompetencijos vertinimo metodiką (adaptuotą Ullrich ir de Muynck anketą), kurią sudaro 45 teiginiai, atskleidžiantys socialinès kompetencijos raiškos ypatumus. Ši metodika atskleidžia septynis faktorius: F1 - bendraji pasitikèjimą savimi, F2 atsparumą nesèkmèms ir kritikai, F3 - gebejjima reikšti jausmus, F4 - gebejjimą paprašyti paslaugos, F5 - nenuolaidumą, F6 - galejjimą pareikalauti, F7 - nesijautimą kaltu. Taip pat buvo surinkta informacija apie tiriamuju lyti ir veikla.

Tyrimo rezultatai apdoroti matematinès statistikos metodais. Buvo apskaičiuojamas skirtingo fizinio aktyvumo ir skirtingos lyties moksleiviu grupių atsakymų $i$ klausimus pasirinkimų skaičiaus vidurkis. Taip pat naudotas chi kvadrato kriterijus, kadangi šis metodas taikomas skirtumo tarp grupiu rodikliu reikšmingumui nustatyti, kai duomenys suskirstyti kategorijomis.

Tyrimas pradètas nuo 2004 metu atsitiktiniu būdu pasirinktose dviejose Kauno bendrojo lavinimo vidurinėse mokyklose. Apklausti 13-15 metu moksleiviai - 400 respondentų: 186 merginos ir 214 vaikinų. Respondentai buvo parinkti netikimybiniu tiriamujuc grupių parinkimo būdu, t. y. kai tiriamuju pasiskirstymas populiacinėje grupejje nèra žinomas.

\section{REZULTATAI}

Išanalizavus tyrimo rezultatus, susijusius su F1 faktoriumi (bendrojo pasitikejjimo savimi), kuris atskleidžia bendraji pasitikejjimą savimi konkrečiai neapibrèžtomis situacijomis, savo svarbumo suvokimą bei ryžtingumą, galima teigti, kad labiau pasikliauja savimi lyties aspektu ir sportuojantys vaikinai (vidutinis pasirinkimų skaičius - 4,03), ir sportuojančios merginos (vidutinis pasirinkimu skaičius - 3,97), tačiau rezultatu skirtumas statistiškai nereikšmingas $-p>0,05$.

Veiklos aspektu sportuojantys vaikinai (vidutinis pasirinkimu skaičius - 4,03) ir sportuojančios merginos (vidutinis pasirinkimų skaičius - 3,97) labiau pasikliauja savimi negu nesportuojantys vaikinai (vidutinis pasirinkimų skaičius - 3,71 ) ir nesportuojančios merginos (vidutinis pasirinkimu skaičius - 3,62). Rezultatų skirtumas statistiškai reikšmingas $(\mathrm{p}<0,05)$. 
Analizuojant tyrimo rezultatus, susijusius su F2 faktoriumi (atsparumo nesėkmèms ir kritikai), kuris leidžia įvertinti tiriamuju gebejimą priimti aplinkiniu negatyvius vertinimus ir nepritarimą, galima teigti, kad tarp atsakymu $\mathfrak{i}$ šio faktoriaus teiginius ryškiausiai lyties aspektu išsiskyrè nesportuojantys vaikinai (vidutinis pasirinkimu skaičius - 4,11) ir nesportuojančios merginos (vidutinis pasirinkimų skaičius - 4,14) sportuojančiu vaikinų (vidutinis pasirinkimų skaičius - 4,04) ir sportuojančių merginų (vidutinis pasirinkimu skaičius - 3,99) atžvilgiu, tačiau rezultatų skirtumas statistiškai nereikšmingas - $\mathrm{p}>0,05$.

Analizuojant tyrimo rezultatus, susijusius su F3 faktoriumi (gebejimu reikšti jausmus), kuris leidžia ivertinti tiriamuju gebėjimą parodyti savo teigiamus ir neigiamus jausmus, juos verbalizuoti, aptarti su kitu asmeniu, galima teigti, kad tarp atsakymų i šio faktoriaus teiginius lyties aspektu išsiskyre sportuojantys vaikinai (vidutinis pasirinkimų skaičius - 3,49) ir sportuojančios merginos (vidutinis pasirinkimu skaičius 3,61 ), tačiau rezultatu skirtumas statistiškai nereikšmingas $-p>0,05$.

Veiklos aspektu teigiamus jausmus daugiau parodo sportuojančios merginos (vidutinis pasirinkimų skaičius - 3,61) nei nesportuojančios (vidutinis pasirinkimų skaičius - 3,01). Rezultatu skirtumas statistiškai reikšmingas $-p<0,05$.

Analizuojant tyrimo rezultatus, susijusius su F4 faktoriumi (gebejimu paprašyti paslaugos), nustatyta, kad sportuojantys vaikinai (vidutinis pasirinkimų skaičius - 3,97) ir sportuojančios merginos (vidutinis pasirinkimų skaičius 3,95 ) labiau geba kontaktuoti su pažistamais ir nepažistamais žmonėmis negu nesportuojantys vaikinai (vidutinis pasirinkimų skaičius - 3,52 ) ir nesportuojančios merginos (vidutinis pasirinkimu skaičius - 3,86), tačiau rezultatų skirtumas statistiškai nereikšmingas $-\mathrm{p}>0,05$.

Veiklos aspektu labiau geba kontaktuoti su pažistamais ir nepažistamais žmonėmis sportuojantys (vidutinis pasirinkimų skaičius - 3,97) negu nesportuojantys vaikinai (vidutinis pasirinkimu skaičius - 3,52). Rezultatu skirtumas statistiškai reikšmingas $-\mathrm{p}>0,05$.

Analizuojant tyrimo rezultatus, susijusius su F5 faktoriumi (nenuolaidumu), kuris įvertina tiriamojo elgesi kitų žmonių keliamų reikalavimų atžvilgiu, galima teigti, kad vertinant šio faktoriaus teiginius ryškiausiai lyties aspektu išsiskyrè nesportuojantys vaikinai (vidutinis pasirinkimu skaičius $-3,81$ ) ir nesportuojančios merginos (vidutinis pasirinkimu skaičius - 3,79), tačiau rezultatų skirtumas statistiškai nereikšmingas $-\mathrm{p}>0,05$.

Veiklos aspektu sportuojančios merginos (vidutinis pasirinkimų skaičius - 3,46) geba labiau nusileisti negu nesportuojančios merginos (vidutinis pasirinkimų skaičius - 3,79). Rezultatu skirtumas statistiškai reikšmingas $-p>0,05$.

Analizuojant tyrimo rezultatus, susijusius su F6 faktoriumi (galejimu pareikalauti), galima teigti, kad ryškių skirtumų lyties ir veiklos aspektu nepastebėta. Nesportuojantys vaikinai (vidutinis pasirinkimų skaičius - 3,70) labiau geba viešoje vietoje išsakyti pretenzijas ir suformuluoti savo reikalavimus negu sportuojantys vaikinai (vidutinis pasirinkimų skaičius - 3,66), sportuojančios merginos (vidutinis pasirinkimu skaičius - 3,68 ) ir nesportuojančios merginos (vidutinis pasirinkimu skaičius - 3,63), tačiau rezultatų skirtumas tarp grupių statistiškai nereikšmingi - $p>0,05$.

Analizuojant tyrimo rezultatus, susijusius su F7 faktoriumi (nesijautimu kaltu), kuris ¿̇vertina kaltès jausmą, kylanti nepatenkinus kitu žmonių prašymų arba reikalavimų konkrečiomis situacijomis, taip pat neapibrèžtą kaltès jausmą, ryškiausiai nuomonė lyties aspektu išsiskyrè tarp nesportuojančiu vaikinu (vidutinis pasirinkimu skaičius - 3,32) ir nesportuojančių merginu (vidutinis pasirinkimų skaičius - 3,45), veiklos aspektu - tarp nesportuojančių merginų (vidutinis pasirinkimu skaičius - 3,45) ir sportuojančių merginų (vidutinis pasirinkimų skaičius 3,29), tačiau rezultatu skirtumas statistiškai nereikšmingas $-\mathrm{p}>0,05$.

Išanalizavus vertybinių orientacijų raiškos tyrimo rezultatus nustatyta, kad orientacija į bendravimą smarkiai skiriasi veiklos aspektu: nesportuojantys vaikinai (vidutinis pasirinkimų skaičius 9,70) labiau linkę bendrauti už sportuojančius vaikinus (vidutinis pasirinkimų skaičius - 8,23). Sportuojančių ir nesportuojančių vaikinų orientacijos i bendravimą raiškos rezultatu skirtumas statistiškai reikšmingas $-\mathrm{p}<0,05$ (1 lent.).

Lyties aspektu nesportuojantys vaikinai (vidutinis pasirinkimų skaičius - 9,70) labiau linkę bendrauti už nesportuojančias merginas (vidutinis pasirinkimų skaičius - 8,47). Rezultatų skirtumas statistiškai reikšmingas $-\mathrm{p} \leq 0,05$.

Lyties aspektu tarp sportuojančiuc ir nesportuojančių vaikinų bei sportuojančių ir nesportuojančiu merginų orientacijos į save tyrimo rezultatai parodè, kad statistiškai reikšmingu rezultatu vidurkiu skirtumo nėra $(\mathrm{p}>0,05)$ (2 lent.). 


\begin{tabular}{|c|c|c|c|c|c|}
\hline \multirow{5}{*}{$\begin{array}{l}1 \text { lentelè. Orientacijos i } \\
\text { bendravimą skirtumo } \\
\text { patikimumas veiklos } \\
\text { aspektu }\end{array}$} & \begin{tabular}{|ll} 
& Statistiniai rodikliai \\
Kontingentas & \\
\end{tabular} & Atvejų skaičius & \begin{tabular}{|c|}
$\begin{array}{c}\text { Vidutinis pasirinkimų } \\
\text { skaičius }\end{array}$ \\
\end{tabular} & $\mathbf{p}$ & $\alpha$ \\
\hline & Sportuojantys vaikinai & 118 & 8,23 & \multirow{2}{*}{0,02} & \multirow[b]{2}{*}{$\mathrm{p}<0,05$} \\
\hline & Nesportuojantys vaikinai & 96 & 9,70 & & \\
\hline & Sportuojančios merginos & 82 & 8,79 & \multirow{2}{*}{0,60} & \multirow[b]{2}{*}{$\mathrm{p}>0,05$} \\
\hline & Nesportuojančios merginos & 104 & 8,47 & & \\
\hline \multirow[t]{5}{*}{$\begin{array}{l}2 \text { lentelè. Orientacijos } \\
\text { i save skirtumo patiki- } \\
\text { mumas veiklos aspektu }\end{array}$} & \begin{tabular}{|ll} 
& Statistiniai rodikliai \\
Kontingentas & \\
\end{tabular} & Atvejų skaičius & $\begin{array}{c}\begin{array}{c}\text { Vidutinis pasirinkimų } \\
\text { skaičius }\end{array} \\
\end{array}$ & $\mathbf{p}$ & $\alpha$ \\
\hline & Sportuojantys vaikinai & 118 & 7,81 & \multirow[b]{2}{*}{0,89} & \multirow[b]{2}{*}{$\mathrm{p}>0,05$} \\
\hline & Nesportuojantys vaikinai & 96 & 7,90 & & \\
\hline & Sportuojančios merginos & 82 & 9,29 & \multirow[b]{2}{*}{0,23} & \multirow[b]{2}{*}{$\mathrm{p}>0,05$} \\
\hline & Nesportuojančios merginos & 104 & 10,00 & & \\
\hline \multirow[t]{5}{*}{$\begin{array}{l}3 \text { lentelè. Orientacijos i } \\
\text { veiklą skirtumo patiki- } \\
\text { mumas veiklos aspektu }\end{array}$} & $\begin{array}{ll}\text { Kontingentas } & \text { Statistiniai rodikliai } \\
\end{array}$ & Atvejų skaičius & $\begin{array}{l}\text { Vidutinis pasirinkimų } \\
\text { skaičius }\end{array}$ & $\mathbf{p}$ & $\alpha$ \\
\hline & Sportuojantys vaikinai & 118 & 10,36 & \multirow{2}{*}{0,25} & \multirow{2}{*}{$\mathrm{p}>0,05$} \\
\hline & Nesportuojantys vaikinai & 96 & 9,71 & & \\
\hline & Sportuojančios merginos & 82 & 9,61 & \multirow{2}{*}{0,02} & \multirow[b]{2}{*}{$\mathrm{p}<0,05$} \\
\hline & Nesportuojančios merginos & 104 & 8,13 & & \\
\hline
\end{tabular}

Veiklos aspektu nustatytas statistiškai reikšmingas rezultatų vidurkis tarp sportuojančiu vaikinu (vidutinis pasirinkimu skaičius - 7,81) ir sportuojančių merginų (vidutinis pasirinkimu skaičius - 9,29) $(p<0,05)$ bei tarp nesportuojančiu vaikinų (vidutinis pasirinkimų skaičius - 7,90) ir nesportuojančių merginu (vidutinis pasirinkimu skaičius - 10,00) $(\mathrm{p}<0,05)(2$ lent. $)$.

Orientacija ị veiklą būdinga sportuojantiems paaugliams. Lyginant orientacijos ị veiklą tyrimo rezultatus galima teigti, kad kryptinga orientacija i veiklą būdinga tiek sportuojantiems, tiek nesportuojantiems vaikinams. Tarp šių grupių nustatytas rezultatų skirtumas statistiškai nereikšmingas $p>0,05$. Atsakymų rezultatų vidurkių skirtumas statistiškai reikšmingas tarp sportuojančių (vidutinis pasirinkimų skaičius - 9,61) ir nesportuojančių (vidutinis pasirinkimų skaičius - 8,13) merginu bei nesportuojančių merginų ir vaikinų $(\mathrm{p}<0,05)$ (3 lent.).

\section{REZULTATŲ APTARIMAS}

Paauglių socialinès kompetencijos tema nèra plačiai analizuota, tačiau šios srities studentu tyrimu pavyko rasti: L. Danielūtès (2005) (Sporto vadybininkų profesinio rengimo analizè (turizmo ir sporto vadybos specialybès studentų pavyzdžiu);
N. Dalinkevičiūtès (2007) (Studiju programos „Turizmo ir sporto vadyba" studentų socialinès kompetencijos ypatumai); J. Menclerytès (2006) (Kauno miesto turizmo organizacijų vadybininkų socialinès kompetencijos bei komunikacinès elgsenos ypatumai); R. Lekavičienès (2001) (Socialinès kompetencijos psichologiniai kriterijai ir vertinimai).

Taip pat nemažai pavyko rasti užsienio autorių, kurie nagrinejja ịvairaus amžiaus žmonių socialinès kompetencijos ypatumus: L. A. Boyum, R. D. Parke (1995) (The role of family emotional expressiveness in the development of children's social competence), N. Desbiens ir kt. (1998) (Social competence, social status and social affiliations of students with behavior problems: Implications for school intervention), K. Dodge ir J. Price (1994) (On the relation between social information processing and socially competent behavior in early school-age children).

Paaugliu vertybines orientacijas plačiai yra išnagrinėję R. Puniškienė ir S. Laskienė (2006) (Sportuojančiu paaugliu vertybiniu orientaciju. asmenybes savybiu ir savigarbos ypatumai), S. Šukys (2001) (Sportine veikla, kaip paaugliu vertybiniu orientaciju, asmenybes savybiu ir socialinio elgesio formavimosi veiksnys).

Išanalizavus septynių socialinès kompetencijos faktoriu tyrimo rezultatus pastebètas skirtumas 
tarp sportuojančių ir nesportuojančių paauglių. Reikšmingai pasitiki savimi sportuojantys vaikinai ir sportuojančios merginos, geba labiau parodyti savo teigiamus ir neigiamus jausmus, juos verbalizuoti, aptarti su kitu asmeniu sportuojančios merginos, daugiau kontaktuoja su pažistamais ir nepažįstamais žmonėmis sportuojantys vaikinai. Nesportuojantiems paaugliams būdingas nenuolaidumas.

Apibendrinant paauglių vertybinių orientacijų tyrimą galima teigti, kad sportuojančių paauglių vertybinių orientacijų skalëje smarkiai išsiskiria kryptinga orientacija į veiklą. Veikla yra asmenybės raidos pagrindas, o svarbiausias sportuojančiu paauglių tikslas yra sportinė veikla, saviraiška, savęs realizavimas, sportinių rezultatú siekimas. Tai, kad mūsu tyrimo rezultatai rodo orientaciją $i$ sportuojančiu paauglių veiklą, tiesiogiai yra susiję su sportinès veiklos kryptingumu ir galimybe gauti informaciją apie savo veiklos rezultatus, jaustis išmanančiam tam tikroje srityje, jaustis reikšmingam tarp bendraamžių. Taip pat nustatyta, kad nesportuojantys vaikinai labiau linkę patenkinti savo bendravimo poreiki, bendravimas jiems yra saviraiškos priemonè, visuomeninio statuso igavimas. Daugumos autorių (Brettschneider, Heim, 1997; Hagger, 2005) nuomone, paauglių orientacija i save siejama su šio amžiaus tarpsnio psichosocialinès ir kognityvinès brandos ypatumais. Atlikto tyrimo duomenys rodo, kad sportas neturi didelès įtakos paauglių orientacijos i save raiškai.

Tyrimo rezultatai atitinka $\mathrm{R}$. Puniškienès ir S. Laskienès (2006) gautuosius, kurie teigia, kad orientacija i bendravimą smarkiai skiriasi veiklos aspektu: sportuojančios merginos labiau linkę bendrauti nei sportuojantys vaikinai; nenustatyta statistiškai reikšmingo skirtumo tarp grupių orientacijos i save rezultatú, sportuojantys paaugliai labiausiai orientuoti i veiklą.

\section{IŠVADOS}

1. Reikšmingai pasitiki savimi sportuojantys vaikinai ir sportuojančios merginos; geba parodyti savo teigiamus ir neigiamus jausmus, juos verbalizuoti, aptarti su kitu asmeniu sportuojančios merginos; kur kas labiau geba kontaktuoti su pažįstamais ir nepažistamais žmonèmis sportuojantys vaikinai.

2. Nesportuojantiems paaugliams būdingas nenuolaidumas.

3. Kryptinga orientacija ị bendravimą daug būdingesnè nesportuojantiems vaikinams.

4. Kryptinga orientacija ì veiklą labai būdinga sportuojančioms merginoms ir sportuojantiems vaikinams.

5. Kryptinga orientacija ị save būdinga nesportuojantiems paaugliams.

\section{LITERATŪRA}

Boyum, L. A., Parke, R. D. (1995). The role of family emotional expressiveness in the development of children's social competence. Journal of Marriage and the Family, 57 (3), 593-608.

Brettschneider, W., Heim, R. (1997). Identity, Sport, and Youth Development. In K. Fox (Ed.), The Physical Self: From Motivation to Well-Being. Champaign, IL: Human Kinetics Publishing.

Dalinkevičiūtè, N. (2007). Studiju programos ,, Turizmo ir sporto vadyba" studentu socialinès kompetencijos ypatumai: magistro teziu santrauka. Kaunas: LKKA.

Danieliūtè, L. (2005). Sporto vadybininku profesinio rengimo analizé (turizmo ir sporto vadybos specialybess studentu pavyzdžiu): magistro teziu santrauka. Kaunas: LKKA.

Danish, S. J., Taylor, E. T., Fazio, R. J. (2003). Enhancing adolescent development through sports and leisure. In G. R. Adams, D. Berzonsky (Eds.), Handbook of Developmental Psychology. Blackwell Handbook of Adolescence. Blackwell Publishing.

Desbiens, N., Royer, E., Fortin, L., Bertrand, R. (1998). Social competence, social status and social affiliations of students with behavior problems: Implications for school intervention. Science-et-Comportement, 26 (2), 107-127.

Dodge, K., Price, J. (1994). On the relation between social information processing and socially competent behavior in early school-age children. Child Development, 65 , $1385-1397$.
Erpenbeck, J. (1998). Kompetencentwicklung als Foorschunsfrage. Bulletin QUEM, 2-3, 64-79.

Grendstad, N. M. (1996). Mokytis - tai atrasti: susiliejančio ugdymo principai ir praktiniai darbo būdai. Vilnius: Margi raštai.

Hart, D., Atkins, R. (1999). Family influences on the formation of moral identity in adolescence: Longitudinal analyses. Journal of Moral Education, 28 (3), 375-386.

Hinsch, R., Pfingstein, U. (1998). Gruppentraining social Kompetenzen. Weinheim: Belz.

Klomsten, T. A., Skaalvik, E. M., Espness, A. G. (2004). Physical self-concept and sports: Do gender differences still exsist? Iš Sex Roles: a Journal of Research [interaktyvus]. [žiūrèta 2008-03-26]. Prieiga internetu:

http://www.findarticles.com/p/articles/mi_m2294/is 12 50/ai_113419430

Lekavičienè, R. (2004). Socialinès kompetencijos kriteriju problema: studentų socialinių igūdžių ir socialinio prioriteto santykio tyrimas. Ugdymas. Küno kultūra. Sportas, $1,30-36$.

Lekavičienè, R. (2001). Socialinès kompetencijos psichologiniai kriterijai ir vertinimai. Kaunas: Vytauto Didžiojo universitetas.

Malinauskas, R. (2006). Sporto pedagogu ir sportininku socialinio psichologinio rengimo ypatumai. Vilnius: Lietuvos sporto informacijos centras. 
Martinkus, B., Neverauskas, B., Sakalas, A. (2002). Vadyba: specialistu rengimo kiekybinis ir kiekybinis aspektas. Kaunas: Technologija.

Mencleryte, J. (2006). Kauno miesto turizmo organizaciju vadybininku socialines kompetencijos bei komunikacinès elgsenos ypatumai: magistro teziu santrauka. Kaunas: LKKA.

Moreno, J. A., Cervello, E. (2005). Physical self-perception in Spanish adolescents: Effects of gender and involvent in physical activity. Journal of Human Movement Studies, 48, 291-311.

Oweis, P., Spinks, W. L. (2001). Psychological outcomes of physical activity: A theoretical perspective. Journal of Human Movement Studies, 40, 351-375.

Puniškienė, R. Laskienė, S. (2006). Sportuojančių paaugliu vertybiniu orientacijuc, asmenybès savybiu ir savigarbos ypatumai. Sporto mokslas, 4, 48-54.

Sauer, J. (1998). Von der Weiterbildung für Kompetenzentwicklung als politischer Auftrag. Bullrtin QUEM, $2-3,69-76$.
Sookol, J. (2001). Idealaus vadybininko portretas. Vadovo pasaulis, 9, 4-10.

Šertvytienè, D., Laskienè, S. (2008). Sportuojančiu paaugliu asmenybės kryptingumo raiška. Küno kultūra ir sportas universitete-2008: tarptautines konferencijos pranešimu medžiaga (pp. 96-97). Palanga.

Šukys, S. (2001). Sportinè veikla, kaip paaugliu vertybiniu orientaciju, asmenybes savybiu ir socialinio elgesio formavimosi veiksnys: edukologijos daktaro disertacija. Kaunas: LKKA.

Weiss, M. R., Amorose, J. A. (2005). Children's self-perceptions in the physical domain: Between-and within-age variability in level, accuracy, and sources of perceived competence. Journal of Sport \& Exercise Psychology, 27, $226-244$.

Елисеев, О. П. (2000). Практикум по психологии личности. Санкт Петербург. С. 202.

\title{
VALUE ORIENTATIONS OF ADOLESCENTS ENGAGED IN SPORTS AS FACTORS OF THEIR SOCIAL COMPETENCE
}

\author{
Dovilè Šertvytienė, Skaistė Laskienė \\ Lithuanian Academy of Physical Education, Kaunas, Lithuania
}

\begin{abstract}
Manifestation of value orientations of adolescents has many aspects, as adolescence is much influenced by the peculiarities of psychosocial and cognitive development, various internal and external factors, thus research on value orientations always remains urgent. Social competence of a person is understood as the person's ability to act, it is determined by the person's knowledge, abilities and skills, attitudes and personal qualities, as well as values.

The aim of the research was to establish and evaluate the value orientations of adolescents as factors of their social competence in the aspect of gender.

The research participants were 400 (186 girls and 214 boys) 13-15 year-old pupils from Kaunas secondary schools. The groups of respondents were randomly selected to participate in the research.

Applying the method of a questionnaire survey we established the value orientations and the peculiarities of social competence of the respondents. For value orientations the respondents were given a questionnaire prepared by a Czech psychologist B. Bass (Елисеев, 2000). The questionnaire included three orientations: towards oneself, towards communication and towards activities. Peculiarities of social competence were evaluated applying R. Lekavičienè (2001) methods of evaluation of social competence (adapted questionnaire from Ullrich and Muynck). The questionnaire involved 45 statements revealing the peculiarities of the manifestation of social competence.

The questionnaire data were processed using methods of mathematical statistics. The differences between the groups were estimated applying Chi-square criterion.

It was established that pupils, both boys and girls, engaged in sports more relied on themselves and could communicate with people who they knew or did not know. Purposeful orientation towards communication was more common among girls engaged in sports and boys not engaged in sports. Orientation towards activities was more typical of girls and boys engaged in sports, and orientation toward oneself - girls and boys not engaged in sports.
\end{abstract}

Keywords: sport, social competence, value orientations.

Gauta 2008 m. rugsejjo $30 \mathrm{~d}$.

Received on September 30, 2008

Priimta 2008 m. gruodžio $9 \mathrm{~d}$.

Accepted on December 9, 2008
Dovilè Šertvytienė

Lietuvos kūno kultūros akademija

(Lithuanian Academy of Physical Education)

Sporto g. 6, LT-44221 Kaunas

Lietuva (Lithuania)

Tel +37068217981

E-mail dovile.sertvytiene@gmail.com 